原著

\title{
高歯令者破裂脳動脈瘤直達手術例の転帰の予測
}

\author{
八木 伸一 ${ }^{1}$, 貫井 英明 $^{1}$, 西ヶ谷和之 ${ }^{1}$, 宮沢 伸彦 $^{1}$ \\ 堀越 徹, 深町 彰 ${ }^{2}$, 佐々木秀夫 ${ }^{3}$
}

\section{Predicting Outcome Following Direct Surgery in Patients with Ruptured Cerebral Aneurysm over 70 Years Old}

\author{
Shinichi Yagi, M.D., ${ }^{1}$ Hideaki NukuI, M.D., ${ }^{1}$ Kazuyuki NishigaYA, M.D., ${ }^{1}$ Nobuhiko \\ Mryazawa, M.D., ${ }^{1}$ Toru Horikoshi, M.D., ${ }^{1}$ Akira Fukamachi, M.D., ${ }^{2}$ and \\ Hideo SASAKI, M.D. ${ }^{3}$ \\ Departments of Neurosurgery, ${ }^{1}$ Yamanashi Medical University, Yamanashi, ${ }^{2}$ Nasu \\ Neurosurgical Hospital, Nasu, and ${ }^{3}$ Kofu Jonan Hospital, Kohu, Japan
}

Summary: To determine what preoperative factors predict surgical outcome, we reviewed the management of 89 patients with ruptured cerebral aneurysm over 70 years old treated at their institutions until 1994. Multivariate logistic analysis of several risk factors revealed that preoperative consciousness, aneurysm location and patient age had an independent correlation with surgical outcome. We propose a simple classification for patients at high risk for unfavorable outcome. The grade of a patient from 0 to 3 obtained by adding the points value for each factor: Risk-Grade $=$ patient over 80 years old (no: 0 or yes: 1) + disturbance of consciousness (no: 0 or yes: 1) + basilar aneurysm (no: 0 or yes: 1). A prospective analysis of this grading scale on 25 surgically treated patients with ruptured cerebral aneurysm over 70 years old after 1995 demonstrated a strong correlation with surgical outcome. The rate of recovery for skills of daily living was $72 \%$ in patients of Risk-Grade 0 , $46 \%$ in patients of Risk-Grade 1 , and $0 \%$ in patients of Risk-Grade 2 . This classification can be used to identify the surgical risk of patients preoperatively, determine the operative indication, and also provides a system that allows for comparison of results from different centers and different techniques.

\author{
Key words: \\ - ruptured cerebral \\ aneurysm \\ - elderly patient \\ - surgical outcome \\ - risk factor \\ - classification
}

Surg Cereb Stroke (Jpn) 27: 210-215, 1999

\section{はじめに}

高齢者社会を迎え, 日常臨床上, 高齢者の脳動脈瘤に遭 遇する機会が増加している，最近では，高齢者脳動脈瘤に 対して積極的な治療を行っている施設から, その治療成績 などに関する報告も増えているが，手術適応を含めた治療 上の問題点はいまだ解決されていない，われわれは以前よ

${ }^{1}$ 山梨医科大学 脳神経外科, ${ }^{2}$ 那須脳神経外科病院, ${ }^{3}$ 甲府城南病院 脳神経外科(受稿日 1998.9.25)〔連絡先： $7409-3898$ 山梨県中 巨摩郡玉穂町下河東 1110 山梨医科大学 脳神経外科 八木伸一〕〔Mailing address: Shinichi YAGI, M.D., Department of Neurosurgery, Yamanashi Medical University, 1110 Shimokato, Tamaho-cho, Nakakoma-gun, Yamanashi 409-3898, Japan〕
り，発症前に自立した日常生活が可能で重篤な全身合併症 のない 70 歳以上の高齢者に対して，若年者と同様に積極 的に破裂脳動脈瘤に対する直達手術を行ってきた。今回, これまでの治療成績をもとに転帰に影響する危険因子を決 定し，治療成績を術前に予想して治療方針の決定や治療に 反映させるための Risk-Gradeを作成した。 


\section{対象および方法}

1994 年までの高齢者破裂脳動脈瘤に対して直達手術を 施行した 89 例の治療成績を分析し，転帰に影響を及ぼし た，術前に容易に規定可能な因子を選び出した。これらの 因子を点数化し, 加算点から grade 分類(Risk-Grade)した. 1995 年以降に経験した高齢者破裂脳動脈瘤症例 25 例に対 してこの Risk-Grade を適応させ，その問題点を検討した.

これまでのわれわれの高齢者破裂脳動脈瘤に対する治療 方針は，基本的に若年者と同様で，発症前に自立した日常 生活が可能で, 全身麻酔の禁忌となる重篤な全身合併症の ない症例のうち, 術前の状態が付帯事項を除いたHunt and Kosnik grade IからIVまでの症例を対象に, 来院後 可及的早期に脳動脈瘤に対する直達手術を行うことであっ た。

転帰の判定は退院時の状態と追跡調查を加味して,

Table 1 Surgical outcome in 89 patients treated until 1994

\begin{tabular}{lrr}
\hline \multirow{2}{*}{ Characteristic } & \multicolumn{2}{c}{ Outcome } \\
\cline { 2 - 3 } & Favorable & Unfavorable \\
\hline Patient age (yrs) & $35(57 \%)$ & $26(43 \%)$ \\
$70-74$ & $10(55 \%)$ & $8(45 \%)$ \\
$75-79$ & $4(40 \%)$ & $6(60 \%)$ \\
$>80$ & & \\
Hunt \& Kosnik grade & $39(78 \%)$ & $11(22 \%)$ \\
I, II & $5(25 \%)$ & $15(75 \%)$ \\
III & $5(26 \%)$ & $14(74 \%)$ \\
IV & & \\
Location of aneurysm & $43(58 \%)$ & $31(42 \%)$ \\
Ant. circulation & $6(40 \%)$ & $9(60 \%)$ \\
Post. circulation & $1(13 \%)$ & $8(87 \%)]$ \\
[BA tip, BA-SCA & $5(83 \%)$ & $1(17 \%)]$ \\
[VA-PICA, PC distal &
\end{tabular}

excellent (日常生活不自由なし), good (一部神経症状残存 するが日常生活可能), fair(介助を要するが家庭内生活可 能), poor(寝たきり), deadの5段階評価とし, excellent および goodを favorable outcome (転帰良好) とした。

統計学的検討には, 単変量解析にて各危険因子と転帰と の関係を分析し，さらに，多変量解析にて転帰の予測に有 意な因子を決定した。それぞれ $\chi^{2}$ 検定を使用し, $\mathrm{p}<0.05$ をもって有意とした。

\section{結 果}

1994 年までの自験例 89 例の治療成績では，全体として 89 例中 49 例， $55 \%$ が転帰良好であった。年齢別では 70 か ら 79 歳に比較し, 80 歳以上では治療成績は芳しくなかっ た. 術前 gradeではHunt and Kosnik grade I, IIに比し grade III, IVの成績は不良であった。動脈瘤の部位別で はテント上の動脈瘤に比ベテント下, 特に脳底動脈瘤の治 療成績はきわめて不良であった (Table 1)。これらの結果 に対して統計学的分析を行ったところ, 術前に容易に規定 可能な転帰に影響した因子として年齢, 術前の意識状態, 動脈瘤の部位の 3 因子が選択できた (Table 2)。これらを, 年齢：70-79歳- 0 点, 80 歳以上- 1 点, 術前の意識状 態：Japan Coma Scale I一0点, IIまたはIV-1点, 動 脈瘤部位: 脳底動脈瘤以外一 0 点, 脳底動脈瘤一 1 点とし て点数化した. 3 因子の加算点を Risk-Grade として0から 3の 4段階に分類した (Table 3).

この Risk-Gradeを用いて 1994 年までの 89 例を分類し， 転帰との関係を検討すると, Risk-Grade 0 は37例, RiskGrade 1 は 46 例, Risk-Grade 2 は6例で, 転帰良好例の割

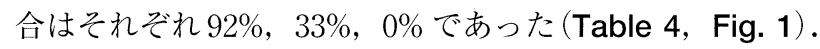
1995 年以降の 25 例を Risk-Grade を用いて分類し，治療 成績との関係について分析すると, Risk-Grade 0 は7 例,

Table 2 Logistic regression analysis of risk factors to surgical outcome

\begin{tabular}{|c|c|c|c|c|c|}
\hline \multirow[b]{2}{*}{ Risk Factor } & \multicolumn{2}{|c|}{ Univariate analysis } & \multicolumn{3}{|c|}{ Multivariate analysis } \\
\hline & $\begin{array}{l}\text { Odd } \\
\text { Ratio }\end{array}$ & p Value & $\begin{array}{l}\text { Odd } \\
\text { Ratio }\end{array}$ & p Value & $\begin{array}{l}\text { Standardized } \\
\text { Estimate }\end{array}$ \\
\hline Over 80 yrs. & 1.99 & 0.32 & 12.7 & 0.013 & 0.44 \\
\hline $\begin{array}{l}\text { Preoperative } \\
\text { grade III, IV }\end{array}$ & 10.28 & $<0.001$ & 21.6 & $<0.001$ & 0.85 \\
\hline $\begin{array}{l}\text { Basilar } \\
\text { aneurysm }\end{array}$ & 12.00 & 0.02 & 78.7 & $<0.001$ & 0.73 \\
\hline Female & 2.05 & 0.19 & 1.14 & 0.87 & 0.03 \\
\hline $\begin{array}{l}\text { Multiple } \\
\text { aneurysms }\end{array}$ & 3.08 & 0.03 & 2.13 & 0.28 & 0.18 \\
\hline Acute stage & 2.87 & 0.02 & 2.58 & 0.14 & 0.26 \\
\hline
\end{tabular}


Table 3 Point values of risk factors for risk-grade determination

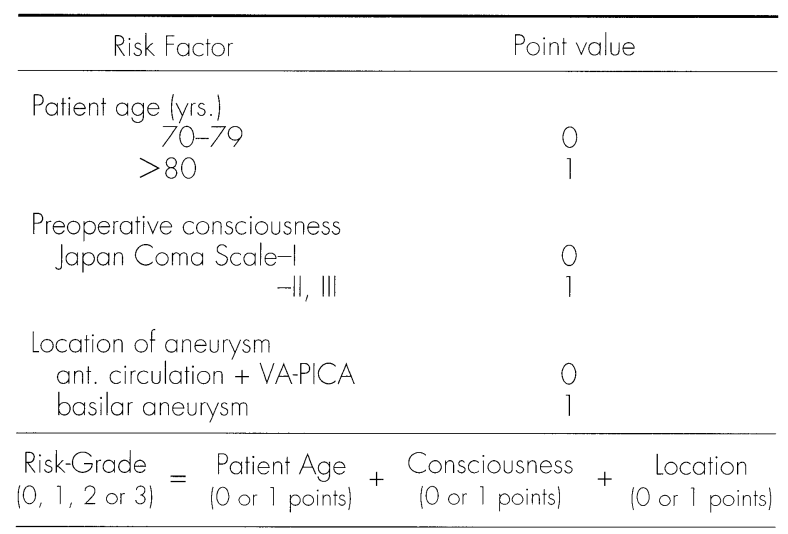

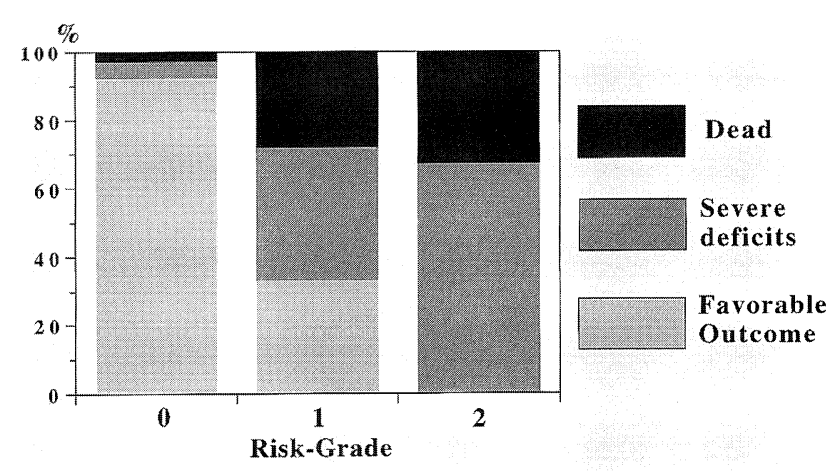

Fig. 1 The rate of outcome according to risk-grade in 89 elderly patients treated surgically until 1994.

Table 4 Retrospective analysis of risk-grade and outcome in 89 elderly patients treated surgically until 1994

\begin{tabular}{ccccccc}
\hline $\begin{array}{c}\text { Risk- } \\
\text { Grade }\end{array}$ & \multicolumn{5}{c}{ Outcome } & \\
\cline { 2 - 5 } & Excellent & Good & Fair & Poor & Dead & Total \\
\hline 0 & 30 & 4 & 2 & 0 & 1 & 37 \\
& $(81 \%)$ & $(17 \%)$ & $(5 \%)$ & & $(3 \%)$ & \\
1 & 10 & 5 & 6 & 12 & 13 & 46 \\
& $(22 \%)$ & $(11 \%)$ & $(13 \%)$ & $(26 \%)$ & $(28 \%)$ & \\
2 & 0 & 0 & 1 & 3 & 2 & 6 \\
& 40 & 9 & 9 & 15 & 16 & 89 \\
\hline Total & & & $(17 \%)$ & $(50 \%)$ & $(33 \%)$ & \\
\hline
\end{tabular}

Risk-Grade 1 は 13 例，Risk-Grade 2 は 5 例で，転州良好 例の割合はそれぞれ 71\%，46\%，0\% であった(Table 5)。

Risk-Grade 0における転帰不良は 1994 年までに 3 例， 1995 年以降 2 例認めたが，これらの原因は脳血管攣縮 1 例, 合併症 2 例 (術後経過中の偶発的脳内出血抢よび急性心筋 梗塞)，また，高齢者に特徵的な症例として，CT上明ら かな LDAの出現はなく，片麻脾を認めなかったにもかか わらず，長期臥床の影響による全身の筋力低下のため歩行 障害が残存した症例, および, 痴呆症状が出現した症例が それぞれ1例であった(Table 6).

\section{考察}

1985 年の 65 歳以上の老年人口の割合は, 全国平均で約 $10 \%$ であったが，96年には 15\%に増加した ${ }^{8)}$.一方，く も膜下出血の年齢別発症頻度では高齢者程上昇率が高く, 高齢者人口の増加により, 高齢者破裂脳動脈瘤の実数は過 去 10-20年間に2-3 倍増となっている ${ }^{1) 26)}$ 。また, 1995 年 現在, 日本人の 70 歳の平均予命は男性 13 歳, 女性 16.8 歳, 80 歳では男性 7.1 歳, 女性 9.5 歳であり ${ }^{9)}$, 高齢者であると いうだけで治療の対象外とはいえない時代である。このよ
Table 5 Application of risk-grade on 25 surgical cases after 1995

\begin{tabular}{cccc}
\hline \multirow{2}{*}{$\begin{array}{c}\text { Risk- } \\
\text { Grade }\end{array}$} & \multicolumn{2}{c}{ Outcome } & \multirow{2}{*}{ Total } \\
\cline { 2 - 3 } & Favorable & Unfavorable & \\
\hline 0 & 5 & 2 & 7 \\
& $(71 \%)$ & $(29 \%)$ & \\
1 & 6 & 7 & 13 \\
2 & $(46 \%)$ & $(54 \%)$ & \\
& 0 & 5 & 5 \\
\hline Total & 11 & $1700 \%)$ & \\
\hline & $(44 \%)$ & $(56 \%)$ & 25 \\
\hline
\end{tabular}

うな状況のもと, 日常臨床で高齢者脳動脈瘤に遭遇する機 会は増加しているが15)12)13)23)26)，われわれの施設にお いても破裂脳動脈瘤手術例に占める高齢者の割合は 90 年 代に入り急増し，現在，全体の $1 / 3$ 以上に達している。

最近では, 高齢者脳動脈瘤に対して諸施設において手術 治療が積極的に行われるようになってきているが, 治療成 績の評価は若年者群と対比させた, Hunt and Kosnikの 
Table 6 Expired and disabled cases classified into Risk-Grade 0

\begin{tabular}{llcccl}
\hline Case & Age/Sex & $\begin{array}{l}\text { H\&K } \\
\text { Grade }\end{array}$ & $\begin{array}{l}\text { Location of } \\
\text { aneurysm }\end{array}$ & Outcome & Causes \\
\hline 1 & $70 / M$ & 1 & MCA & Dead & ICH \\
2 & $74 / F$ & 1 & AcomA & Fair & Vasospasm \\
3 & $77 / F$ & $\|$ & ICPC & Fair & Muscle weakness \\
$4^{*}$ & $70 / M$ & $\mid$ & AcomA & Dead & AMl \\
$5^{*}$ & $72 / F$ & $\|$ & PCA & Fair & Dementia \\
\hline
\end{tabular}

*: treated surgically after 1995, H \& K: Hunt \& Kosnik

$\mathrm{ICH}$ : intracerebral hemorrhage, AMI: acute myocardial infarction

grading systemや World Federation of Neurosurgical Society (WFNS) 分類と転帰との比較により検討されるこ とが多い. Suzukiらは ${ }^{20)}$ ，これらの分類には年齢が考慮 されていないことを指摘し, Hunt and Kosnik 分類を70 歳以上の場合には一段階下げることを提案している.また, 加藤ら $は^{7)}$, 若年者との比較のために, 年齢, 意識レベル およびCT分類を点数化した独自の SAH grading scoreを 作成して転州との相関を検討したが，高齢者では予後良好 期待例でも不良の転帰をとることが多く相関が低いとし た。しかし，これまでに高齢者のみを対象とした分類は存 在しない。そこで，われわれは転帰の予測が可能で, 治療 方針の決定に役立つ分類を作成することとした。このた め，1994年までの自験例 89 例より転帰に影響を及ぼした 因子を選択し，これらを点数化して grade 分類した。この 際，簡便性を重んじ，術前に容易に規定可能な因子を用い， また点数化に際しては可能な限り単純な方法を使用した. この結果，選択した因子は，年歯令，術前の意識状態，動脈 瘤の部位の 3 因子となった。

術前の意識状態については，これまでもHunt and Kosnik grade I，II，すなわち意識清明例の治療成績はお おむね良好である一方, grade III，IV，すなわち意識障 害例については成績不良例が多く手術適応が限定されると いう報告が多い2５５６１3）14１7）22２3）24）27）。これは意識障害 の有無が治療成績に多大な影響を及ぼしていることを反映 している．高齢者では術前の意識障害が術後も遷延して卧 床を余儀なくされた結果，肺炎などの全身合併症が好発し たり ${ }^{2)}$ ，または意識障害は改善しても痴呆症状などが残存 して転帰不良となることが多い. 今回の検討においても術 前 Hunt and Kosnik grade I, IIに比し, grade III, IV の 症例が転帰不良となる危険率は20倍を越え, 意識障害が 転帰不良の重要な危険因子のひとつであると判断した。

脳動脈瘤の部位については, 一般にWillis 輪前半部に比 較して後半部の動脈瘤の治療成績が不良であることは知ら れているが，Willis 輪後半部の中でも椎骨動脈瘤は比較的 容易かつ安全に手術可能な動脈瘤であることが多い。われ
われの結果でも，脳底動脈末端部および脳底動脈一上小脳 動脈分岐部動脈瘤の手術成績はきわめて不良であったが, 椎骨動脈一後下小脳動脈分岐部動脈瘤では良好な成績を得 た。これは，脳底動脈末端部動脈瘤では入院時重症例が多 いこと, 脳底動脈末端部周囲は重要な神経組織や血管で囲 まれて深部に存在するため手術が困難であること，他部位 動脈瘤に比べ臨床的に遭遇する機会が少ないため, 十分な 手術経験を積むのが難しいこと ${ }^{15)}$, 特に高齢者では後頭 下開頭に比しテント上の大開頭では大脳全般に及ぶ影響に より意識障害の遷延や痴呆症状の出現をみやすいことなど があげられる。残念ながら今回の検討では椎骨動脈合流部 から脳底動脈一上小脳動脈分岐部までの脳底動脈本幹部動 脈瘤の症例がなかったが，橋直前に位置し，橋への穿通枝 や脳神経に囲まれたこの領域の手術も困難であることか ら, 脳底動脈本幹部動脈瘤は脳底動脈末端部動脈瘤同様危 険因子となりうると考えられた。

高齢者の定義は，時代によって異なるが 1990 年以降 70 歳以上とすることが一般化し 5) 23) 27)，最近の高齢者脳動 脈瘤の治療についての報告でも70歳以上を一括して議論 することが多い1)2(4) 6) 7) 12) 13) 14) 17) 20) 22) 23) 24) 27)。われわ れは以前より，高齢者を 70-74歳，75-79歳，80歳以上の 3 群に分類し, それぞれの治療成績や問題点を検討した結 果，高齢者の中でも年齢が上昇するに従い治療成績は不良 であり，特に 80 歳以上の超高齢者では手術適応は限られ ることを主張してきた ${ }^{24)}$ 25). 今回の多変量解析による検 討でも 70 から 79 歳に比較して，80歳以上では有意に転帰 が不良である結果を得た。年齢 (80歳以上)も危険因子の ひとつとして, grade 決定に加味した。

その他の要因では多発性動脈瘤の一期的手術および発症 3 日以内の急性期手術において治療成績が不良である傾向 を認めたものの, 多発性動脈瘤では脳底動脈瘤との合併例 が多く，また，急性期手術例では術前状態不良例が多かっ たため, 多变量解析では有意差が得られず, 危険因子には 加えなかった.

点数化にあたっての各因子の重みつけについては, 多変 
量解析にて，意識障害はなし：0, あり：1, 動脈瘤の部 位は脳底動脈以外： 0 , 脳底動脈： 1 , 年齢は 70 から 79 歳： 0,80 歳以上： 1 とした際の回帰係数が意識： 0.85 , 部位：0.73, 年齢：0.44 となり, 年歯令の回㷌係数に比較し て，意識および動脈瘤の部位が回帰係数が大きい結果を得 た。しかし，これまで，80歳以上の症例が単に高齢を理 由に手術適応はないと考えられる傾向にあり, 手術対象と なった 80 歳以上例には術前の状態が良好な症例が多く含 まれやすく12)，われわれの場合も対象とした症例にこの 偏りが存在することは否めない。このため, 80 歳以上の 高齢者についてはより重く評価し，また，grade化の簡便 性のために三つの因子を同等の重みで扱うこととした。

さて, 以上のように決定したRisk-Gradeを1995年以降 の自験例に適応させると, 転帰良好例はそれぞれ Grade 0 ：71\%, Grade 1：46\%, Grade 2：0\%であり，1994 年 までの症例と同様に Grade 1 ではある程度満足な結果， Grade 2では比較的厳しい結果, Grade 3 ではきわめて厳 しい結果を得た。特に, Grade 2 において，全例転州不良 となったことは注目に值する。

Risk-Grade 0における転帰不良例を検討した結果では, 全身合併症に起因した転㷌不良例がほとんどで，高齢者の 特殊性を象徴した結果であった. 高血圧や脳血管障害の既 往などを術前に加味し治療成績を評価した検討において も，既往症は転帰には無関係とする報告もあり ${ }^{4)}$, 既往歴 のみで偶発する全身合併症を術前に予測することは困難で ある。しかし，術後の全身合併症が高齢者の転帰に及ぼす 影響は大きいため2)477)16)17) 19) 20)28), 今回の Risk-Grade では評価できなかった要因であるが，今後さらに検討を必 要とする問題点のひとつである.

今回の Risk-Grade を高齢者破裂脳動脈瘤における手術 適応と治療上の問題点に反映させると, Risk-Grade 0 は積 極的な直達手術の適応となり, 経過中の合併症の予防に留 意する必要があり, Risk-Grade 1 では, 保存的治療の転帰 がきわめて不良であることを考慮すると年3)4)7)27)，手術 適応はあると思われた。これらの症例において治療成績を 向上させる具体的な対策を探し出すことが，高齢者破裂脳 動脈瘤の治療成績の全体的な成績の向上につながると考え られた。

Risk-Grade 2, 3では, 従来の手術法の適応は急性水頭 症による意識障害合併例など特殊な場合に限定されると考 えられた。近年，脳血管内手術による脳動脈溜塞栓術が普 及し，特に grade不良例や全身状態不良例などの開頭手術 困難例に対して積極的に試みられているが，その結果，直 達于術と遜色ない良好な成績が得られているものの, 転帰 不良例の多くは術前の grade 不良例であったとの報告が多 (10)11) 18)。また，高齢者破裂脳動脈溜に対する脳血管内
手術のまとまった報告は少ないため ${ }^{21)}$ ，血管内手術手技 が高齢者に与える影響も明らかではないが，直達手術と比 べ脳の圧排を要しないことは血管内手術の大きな利点であ る。したがって，高度の動脈硬化を有する例が多い高齢者 での操作を工夫すれば ${ }^{21)}$, 直達手術の成績が悪い Riskgrade 2，3のような high risk 症例で血管内手術を試み てよいと考えられる.

これまで高齢者破裂脳動脈瘤の手術適応・治療成績につ いては，ある程度選択された症例を対象とした報告が多か った，今後，多施設，多症例における検討や，直達手術や 脳血管内手術などの治療法の違いによる検討など，統一基 準によるまとまった見解を出す必要があるが，このために も本法は簡便で有用であると思われる。

\section{文献}

1) Fridriksson SM, Hillman J, Saveland H, et al: Intracranial aneurysm surgery in the 8 th and 9th decades of life. Impact on population-based management outcome. Neurosurgery 37: 627-632, 1995

2）平井伸治，小野純一，山浦 晶，ほか：高齢者破裂脳動脈 瘤急性期手術例の検討. 非高齢者例との比較から．脳卒中 の外科 24: $45-50,1996$

3）平田好文，松角康彦，児玉万典，ほ力：高齢者破裂脳動脈 瘤の問題点．特に術後合併症，術後管理面から．Neurol Med Chir (Tokyo) 27: 1066-1072, 1987

4）井川房夫，木矢克造，北岡 保，ほか：高齢者破裂脳動脈 瘤の急性期手術適応の検討. 同一施設による手術療法と保 存療法の比較。脳神経 48: 59-63, 1996

5) Inagawa $\mathrm{T}$ : Management outcome in the elderly patients following subarachnoid hemorrhage. J Neurosurg $\mathbf{7 8}$ : 554-561, 1993

6）加川瑞夫，朝日茂樹：高齢者のクモ膜下出血. 診断と治療 75: 1909-1912, 1987

7）加藤庸子, 佐野公俊, 尾内一如，ほ力：高齢者破裂脳動脈 瘤の問題点. 自然歴と手術適応. Geriat Neurosurg 1: 24-29, 1988

8）厚生省統計協会：全国人口の動向．国民衛生の動向．厚生 の指標 44: 38-41, 1997

9）厚生省統計協会：第 18 回生命表. 国民衛生の動向. 厚生の 指標 44: 441-442, 1997

10) Leber KA, Klein GE, Trummer $\mathrm{M}$, et al: Intracranial aneurysms: a review of endovascular and surgical treatment in 248 patients. Minimally Invasive Neurosurgery 41: 81-85, 1998

11) Malisch TW, Guglielmi G, Vinuela F, et al: Intracranial aneurysms treated with the Guglielmi detachable coil: midterm clinical results in a consecutive series of 100 patients. J Neurosurg 87: 176-183, 1997

12) Moriyama E, Matsumoto $Y$, Meguro $T$, et al: Progress in the management of patients with aneurysmal subarachnoid hemorrhage: A single hospital review for 20 years. Part II: Aged patients. Surg Neurol 44: 528-533, 1995

13）新妻 博, 吉本高志, 鈴木二郎：70歳以上の高齢者脳動脈 瘤根治手術例 35 例の検討. 脳卒中 3: 219-223, 1985

14）貫井英明，金子的実，三塚 繁，ほか：70歳以上の高齢者 破裂脳動脈瘤に㧍ける治療方針。Geriat Neurosurg 2: 55-59, 1989 
15）貫井英明：脳底動脈瘤。山浦晶編集, Neurosurgery Headline 3, 後頭蓋窩病変 II 血管性病変, 三輪書店, 東京, 1998, pp44-58

16）岡一成，黒松千春，高木東介, ほか：高齢者脳動脈瘤治 療の問題点. 脳神経外科 15: 375-379, 1987

17）小野純一, 山上岩男, 磯部勝見, ほか：高齢者破裂脳動脈 瘤急性期手術例に抢ける管理上の問題点. 脳卒中の外科 21: 239-345, 1993

18) Raymond J, Roy D: Safety and efficacy of endovascular treatment of acutely ruptured aneurysms. Neurosurgery 41: 1235-1245, 1997

19）鈴木明文, 安井信之, 波出石弘, ほか：高齢者脳動脈瘤急 性期手術例の転帰不良因子. Neurol Med Chir (Tokyo) 28: 1157-1162, 1988

20) Suzuki A, Yasui N, Hadeishi H, et al: Early surgery in elderly patients with ruptured intracranial aneurysms. Preoperative clinical evaluation and prognosis. Neurol Med Chir (Tokyo) 30: 95-99, 1990

21) Takata H, Iida $T$, Akai $T$, et al: Coil embolization for intracranial aneurysm by direct puncture of the carotid artery in elderly patients. Interventional Neuroradiology
4 (Suppl 1): 75-76, 1998

22）谷川達也, 荒井孝司，米谷博志，ほか：高齢者破裂脳動脈 瘤患者の臨床的特徵と急性期手術成績。脳卒中の外科 $\mathbf{2 4}$ 365-370, 1996

23）上之原広司, 桜井芳明：高齢者脳動脈瘤の問題点. 山浦 晶編集，脳動脈瘤の外科，医学書院，東京，1995, pp51-54

24）八木伸一, 貫井英明, 三塚 繁，ほか：高齢者脳動脈瘤の 手術成績. Geriat Neurosurg 9: 113-117, 1997

25）八木伸一，貫井英明，三塚 繁，ほか：超高齢者脳動脈瘤 の治療方針. 脳外誌 6: 377-381, 1997

26) Yamashita K, Kashiwagi S, Kato S, et al: Cerebral aneurysms in the elderly in Yamaguchi, Japan. Analysis of the Yamaguchi Data Bank of Cerebral Aneurysm from 1985 to 1995. Stroke 28: 1926-1931, 1997

27）安井敏裕, 矢倉久嗣, 小宮山雅樹, ほか：高齢者破裂脳動 脈瘤の治療方針．脳神経外科 20: 651-656, 1992

28) Yoshimoto Y, Kwak S: Age-related multifactorial causes of neurological deterioration after early surgery for aneurysmal subarachnoid hemorrhage. J Neurosurg 83: 984-988, 1995 